\title{
Lexis
}

Journal in English Lexicology

8| 2014

Metaphor Studies in the English Language

\section{Metaphors in English for Law: Let Us Keep Them!}

\author{
Isabelle Richard
}

\section{(2) OpenEdition \\ Journals}

\section{Electronic version}

URL: http://journals.openedition.org/lexis/251

DOI: $10.4000 /$ lexis. 251

ISSN: 1951-6215

\section{Publisher}

Université Jean Moulin - Lyon 3

\section{Electronic reference}

Isabelle Richard, « Metaphors in English for Law: Let Us Keep Them! », Lexis [Online], 8| 2014, Online since 09 January 2014, connection on 19 April 2019. URL : http://journals.openedition.org/lexis/251 ; DOI : $10.4000 /$ lexis. 251

This text was automatically generated on 19 April 2019.

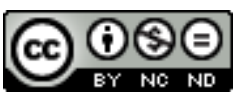

Lexis is licensed under a Creative Commons Attribution-NonCommercial-NoDerivatives 4.0 International License. 


\title{
Metaphors in English for Law: Let Us Keep Them!
}

\author{
Isabelle Richard
}

\section{Introduction: metaphors and legal concepts}

1 Metaphors are based upon an analogical cognitive device which consists in giving access to an unknown domain - the "target domain" that I will call D2 - by using words specific to a well-known domain - the "source domain" that I will call D1. As Trim points out:

[...] the whole nature of human conceptualisation appears to be based on analogy.

Perception of one entity recalls another. [Trim 2007: 18]

2 There lies the major function of metaphors according to Lakoff \& Johnson. They are meant to ease the understanding of D2 by using words belonging to D1: "[...] its primary function is understanding" these authors say [2003: 37] before adding [2003: 160]: "Metaphors [...] are among our principal vehicles for understanding" (also see page 98). The comparison between the two domains is elliptical though, as it is deprived of any explicit sign of comparison. In order to work properly, it relies on elements that both domains have in common. Some writers, such as Morier [1981: 670-671], speak of "preexisting similarities". In this respect, Lakoff \& Johnson state that:

A metaphor can [...] only describe pre-existing similarities. It cannot create similarities. [Lakoff \& Johnson 2003: 154]

Aristotle already underlined this fact in The Poetics, chapter XXII, when he wrote that in order to make a metaphor, one has to identify similarities. It follows that the access to D2 implies some degree of decoding work on the part of the recipient so that he/she can identify these similarities.

4 If we look at this process in a positive way, reasoning by analogy allows one to have access to an abstract domain by making it more concrete generally (a typical example of this is talking about time in terms of space, as in "to take place" - the same goes in French with the corresponding expression avoir lieu). 
If we look at it from a more critical point of view, reasoning by analogy implies taking into account at least two elements which directly impact the way D2 is interpreted. First of all, since D1 and D2 are necessarily distinct (there can be no metaphor if D1= D2) ${ }^{1}$, only some aspects of D1 are used and, similarly, only some aspects of D2 are referenced. The metaphor will use their common points in whole or in part. As a result, a metaphor is always partial:

[...] the simplest of metaphors works according to this selection. [Morier 1981: 676]

6 Second of all, the reason why D1 has been chosen is not to be overlooked: not only is it crucial to how the metaphor works but it also determines the way in which the reader/ recipient will understand D2. In other words, D1 works as a filter.

7 Three conclusions may be drawn from these statements. Firstly, the process by which understanding is facilitated is indirect, which could be seen as an interpretation hardship, yet "minimises the cognitive effort on the part of the recipient" [Cunillera Domènech, 2010: 111] - however, the cognitive effort will depend entirely on who the recipient is, whether or not they know the law and, if they do, what the extent of their knowledge is. Secondly, any metaphor is likely to have an educational goal. Morier [1981: 673] describes such metaphors as being "utilitarian" and adds [1981: 673] that "[it is] typical of the prosaic metaphor [to lead] from the unfamiliar to the familiar". Finally, any metaphor is conceptual. As summarised by Lakoff \& Johnson:

[...] metaphor means metaphorical concept. [Lakoff \& Johnson 2003: 7]

8 In this respect, it is not a mere stylistic effect or a speech ornament. In some instances, metaphors can even carry a meaning that no other figure of speech would convey as efficiently. It is no wonder that legal discourse is rife with metaphors as the law relies heavily on concepts. Given the analogical process on which it is based, the metaphor is indeed, in Berger's words:

[...] particularly apt as a means of explaining complex or abstract ideas. [Berger 2002: 34]

Some writers have even claimed that it cannot do without them:

[...] metaphors are strictly unavoidable in legal language because they are constitutive of legal reasoning. [Morra, Rossi \& Bazzanella 2006: 141]

10 Galonnier [2000: \$12] confirms this standpoint when he quotes Klinck [1991: 360-361]: "legal reasoning is itself metaphorical» because it rests on an inductive (analogical) approach. Indeed, they achieve many things that are very useful to the law: thanks to them, abstract, complex notions can be made more concrete, in particular through a process of reification - as in "to break the law" - or of personification ("the eye of the law", "the arm of the law", "the mouth of the law", "the body of case law", "Lady Justice" to name but a few examples). As Trim noticed:

[...] studies on cross-cultural models [...] suggest that physiological metaphors are

likely to have universal trends. [Trim 2007: 33]

11 He adds, a few pages further:

[personification] can be transmitted from one culture to the next. [Trim 2007: 47]

12 Not surprisingly, the use of body references in legal French is common too. In this respect, Houbert [2008: 1] shows how the expression "the eye of the law" reminds one of the maxim l'oeil de la loi veille and how "the mouth of the law" conjures up Montesquieu's famous quote le juge est la bouche de la loi ("the judge is the mouth of the law"). However, it 
must be specified that metaphors being culture-bound, similar metaphors found in two different languages are not necessarily interpreted in the same way.

This type of metaphor - that Lakoff \& Johnson [2003: 26] call "ontological metaphors" presents ideas or events as if they were entities and is found quite often in English for Law. Nonetheless, other types of metaphor are used, such as those linked to warfare (I will return to this later) or those related to agriculture, climate and water (nature more generally speaking), to mention a few recurrent instances. What is striking is that key legal notions are regularly referred to metaphorically, especially when creations - that is to say abstract things - are concerned. For instance, the law speaks of "intellectual property"/propriété intellectuelle. This is not specific to the law, though. Lakoff \& Johnson [2003: 75] underline the fact that abstract creations are often made more concrete by means of a metaphor that presents them as objects ("His writings are products of his fertile imagination") or as living entities ("The theory of relativity first saw the light in 1905"). The objective, we can assume, is that such notions will be understood and remembered more easily. After all, like most specialist fields, the law is complex and technical. Unlike some of them, its language has to be accessible - not necessarily, and certainly not only, to the average person as we will see later. One undeniable asset of metaphors is that they can work as efficient mnemonic devices that help lawyers themselves get a grasp of, and memorise, the gist of a notion. ${ }^{2}$ Indeed, the vocabulary they use benefits from two powerful advantages: firstly, it is familiar, and secondly, it often triggers images (which is essential as specialists have shown that around $80 \%$ of communication comes across visually). A third element increases this cognitive impact: the analogical process strikes the mind, all the more so when it is surprising and/or symbolical.

However, metaphors do not carry intelligibility virtues only. To begin with, they can be a subtle way to manipulate people. Gingras [1996: 160] specifies that they can be seen as "fallacies", that is to say discursive devices aimed at persuading. In this respect, I will discuss the consequences brought about by some ontological metaphors, notably those of personification. Another argument that reduces their pedagogic power is that any metaphor implies various levels of interpretation: the choice of D1 has to be deciphered in order to see what the metaphor is meant to offer, that is to say, what aspects of D2 are brought to light. But catching the light is not always that obvious. Indeed, even though D1 is supposedly familiar, it does not entail that it is easy to interpret in all metaphors. What they are meant to point out is not always evident. If the recipient does not have the prerequisite knowledge, some of them remain obscure and quite a number leave the reader at a loss. Let us add that the bulk of metaphors in legal speech are "used" or "dead" metaphors - as is generally the case in specialised languages - which, to some writers, is an oxymoron as these so-called metaphors usually go unnoticed because they belong to the legal lexicon ${ }^{3}$ - as opposed to "living" or "live" metaphors. As such, they may have a specific entry in a dictionary. In other words, they are lexicalised. Why does this work against them making them potentially difficult to figure out? Because the context in which they are used is often less telling than that of the "living" metaphors, they may turn out to be harder to decipher. Does that go against them being used in legal language? Not necessarily as I will argue later. Nonetheless, there is one feature that clearly speaks against them: some of them are misleading, either because they are ambiguous or because they impose a vision of the world that wrongly excludes any other interpretation (I will discuss the female personification of the Common Law in this 
respect). I must specify that, in this paper, I will not take into account those metaphors that generate so much incoherence that the message ends up being unintelligible (due to a piling up of metaphors that create a bunch of unrelated images for instance).

Thus, do metaphors in English for Law clarify, distort or blur the message? I will first show how metaphors are inherent to legal English and form a typical part of legal style. However, they are more common in some types of legal text than in others. I did not find many of them in contracts and they also seem to be few and far between in legislative texts. But when they do appear, they play a decisive role as pointed out by Morra, Rossi \& Bazzanella [2006: 148]. Conversely, they are used fairly often in judgments. Berger makes a very interesting point in this respect when he says that:

[...] the judicial opinion is not just a reflection of an opinion and a representation of authority, but also a device that must persuade while maintaining the legitimacy of the legal system. [Berger 2002: 30]

This is particular true when the ruling changes the law:

[...] it is at these moments of change that the need for effective language is most exigent. [...] a critical component of a judge's toolbox is metaphor. [Berger 2002: 30]

Galonnier [2000: 2-5 \& 8] draws a list of the most common metaphors in the former House of Lords' rulings and confirms that their large use answers rhetorical needs. After considering metaphors in legal style, I will look at the manipulative and misleading effects that some metaphors create before turning to how obscure some may be, altogether blurring the message instead of enlightening it and seemingly defeating the initial purpose. Yet, when that is the case, it would be hasty to conclude they should be gotten rid of because of this apparent flaw.

\section{Metaphors are constitutive of legal theory}

Metaphors appear to be ingrained in legal texts and so closely intertwined with the expression of legal concepts that the most fundamental of them are conveyed metaphorically. Scholarship has shown that four major metaphor families seem to be prominent in law: those bringing to mind natural elements, those that conjure up warfare, those that speak of concepts in terms of objects and those that personify (other aspects of everyday life are also used such as animals, sports, architecture, religion and colours). In this way, the very essence of a major aspect of English law, the Common Law, is symbolised through two recurrent metaphors based on nature - would it be far-fetched to say it could be a way to imply that this system of law is "natural"?

\subsection{The Common Law is a tree or a river}

As a matter of fact, the tree metaphor is found in the Common Law system as well as in the civil law system. In both cases, it highlights their idiosyncrasies thanks to the physical characteristics of the tree (trunk, branches and roots) on the one hand, and to the fact that it is a living organism on the other. In the Common Law system, the trunk stands for the law that grew in England from 1066 on (William the Conqueror's victory in Hastings was the starting point of its gradual development in the land) and the branches represent the offspring of this law through colonisation. In the countries where English settlers exported their legal system, the latter evolved and matured in its own way (hence the differences between English law, Canadian law, American law or Australian law for 
instance) just like the branches of a tree grow from the trunk. In civil law systems, the trunk represents Roman law from which legal systems branched out and spread into continental Europe. ${ }^{4}$

Metaphorically, the roots are used similarly in both systems: they point out the fact that they are - literally, one would be tempted to say - rooted in history, which establishes (not to say "proves") their legitimacy. This has not escaped Stirn, Fairgrieve \& Guyomar [2006: 38] when they quote Lévy-Ullmann who stated that:

Positive law steadily goes back in history to times immemorial [...] in England. One can even say that the older a rule of law, the more weight it carries. Authority and time go hand in hand. ${ }^{.}$[Lévy-Ullmann 1999: n. pag.]

The roots are essential. They legitimate and hold together the whole system:

The branches grow indeed, but they have always grown from the same roots. [Sir Pollock 1912: 9]

In this way, the tree metaphor puts forward three key aspects of the Common Law system that anyone is able to identify, for they are simple and straightforward: first, it is strong, stable and sturdy (the trunk); second, it is as solidly rooted in time as roots are in the ground; and third, it is meant to evolve just like any living being - it could even be considered as able to live forever, which would make it virtually indestructible and would endow the Common Law with eternal longevity (botanists know that any "dead" tree harbours a whole variety of living beings: "A dead tree is still alive", the Office National des Forêts- French Forestry Commission - asserts on its website). In other words, the system is here to stay. Sir Pollock [1912: 9] called it "permanent" as a matter of fact.

The river metaphor works just as efficiently as the tree metaphor and points to similar characteristics. Judge Leibson stated in Hilen v. Hays, 673 S.W.2d. 713 (Kentucky Supreme Court) that: "The common law is not a stagnant pool, but a moving stream." In the same way, a 1990 Texas Supreme Court judgment read: "the Common Law is not frozen or stagnant, but evolving" (Reagan v. Vaughn, 804 S.W.2d 463). The water metaphor is also commonly used to mention jurisdictions ("the two streams of jurisdiction, though they run in the same channel, run side by side and do not mingle their waters") or to speak of certain laws ("safe harbor laws"). ${ }^{6}$ This metaphor is also a way to describe how the law works. It is used to distinguish between Common Law and Equity, for instance. In this respect, Loughlan mentions that:

Equity water [is] not mingling with common law water. [Loughlan 2006: 216]

In the same way, Lord Justice Laws wrote in his lecture "Our Lady of the Common Law":

The twin tides of Luxembourg and Strasbourg have swept Wednesbury ${ }^{7}$ away from the foreshore of the law. But though the tides started across the channel their flood is in the common law. [Lord Justice Laws 2012: 16, §27]

5 Fairgrieve \& Muir Watt [2006: 26] insist that the river image is recurrent for two reasons: first of all because it shows that the Common Law draws its legitimacy from the past, and second of all because it evokes longevity and change, as exemplified by this quote from Picard:

In all its history, Common Law changes and yet it does not change. Just like a running river, it is always the same and yet it never is the same. ${ }^{8}$ [Picard 2003: $\mathrm{n}$. pag.]

These two metaphors highlight the same fundamental characteristics of the Common Law - the tree metaphor is a little richer in this respect. Where literal language would need a long explanation or description, one metaphor using a commonplace word (tree, river) 
conjures up three major aspects of a whole system of law by emphasizing its very essence. The tree metaphor offers the additional advantage of being used to describe the three major powers, namely, the «judicial branch", the "legislative branch" and the "executive branch" (similarly, in France, we speak of "the branches of the law"). This is a definite asset for a field as full of notions as the law is: metaphors vividly summarise in a few, often visual words, complex ideas. This is why they are so useful - and some argue they are necessary - in legal language. The very definition of the law itself paves the way for a whole metaphoric field:

Law, in its generic sense, is a body of rules of action or conduct prescribed by controlling authority, and having binding legal force. That which must be obeyed and followed by citizens subject to sanctions or legal consequences in law. [Black's

Law Dictionary, 1991: 612].

The "body" metaphor in the definition has not escaped the reader. The coercion element is to be found in other definitions as well, such as that of Cornu in his Vocabulaire juridique (page 290), which shows that it is not specific to one system of law.

It follows from the definition that non-compliance implies that someone's rights have been encroached upon, in which case the prejudice suffered must and will be redressed with all the might of the law. This is where metaphors of warfare come in.

\subsection{The judicial arena}

"Lady Justice" is associated with four attributes that clearly evoke her main features why "her"? Because the probable reference is that of the Greek goddess of justice Themis (also the goddess of order and social control) whose Latin equivalent was Iustitia (hence the word "justice"). One of these attributes is a sword, another is a shield (the other two are a blindfold and scales, respectively pointing out that her decisions are bias-free and balanced - one thinks of the British civil rules of evidence which have to be "on a balance of probabilities"). The sword punishes injustice - the goddess would pierce the hearts of the unjust with it - and the shield protects the innocent who are unjustly attacked. No wonder that the judicial rhetoric is crammed with war metaphors (a similar pattern is at work in French as pointed out by Picotte [1995: 295-310] for instance). The court procedure in Common Law countries is very telling in this respect: "Even its name begins to tell the story: the adversary system" reads Thornburg's opening sentence [1995: 225]. "In case law, academic literature, professional literature, and in popular culture, a trial is a battle and the lawyer the client's champion" this author adds before providing [1995: 233-236] a large variety of examples showing that trials are spoken of in terms of war. The warfare semantic field is all the less surprising if we remember Mellinkoff's assertion:

The law is a profession of words. [Mellinkoff, 1963: Preface, vii]

Everything is verbal in law, in particular in a court of law. And it just so happens that (in Western cultures at least) debates are often evoked in terms of war. "We have a discourse form structured in terms of battle", Lakoff \& Johnson [2003: 6] point out before adding: "argument is war". The examples they give are quite revealing: "Your claims are indefensible", "He attacked every weak point in my arguments", "His criticisms were right on target", "I demolished his argument", "I've never won an argument with him", "You disagree? Okay, shoot!", "If you use that strategy, he'll wipe you out" [2003: 5-6]. Metaphorically, a court of law is a verbal battlefield. Arguments are attacked. Parties are opponents who need a solid line of defence. The "defendant" is called this way because 
he/she has to defend himself/herself against accusations (the "attacks"). Victims need the protection of the law. Society at large needs and wants to be protected. At some unconscious level, people expect a winner and a loser. As in most sports. But the outcome of a match does not compare to that of a trial. The protection provided by the law is a double-edged weapon as protection seems to be inseparable from punishment. This is it: a sword and a shield. Not surprisingly, these two attributes are used quite often, as exemplified by this quote from Berger:

Anglo-Canadian jurisprudence is replete with metaphorical constructions of the

law: estoppel is a 'shield, not a sword'. [Berger 2002: 36]

From this point of view, metaphors say it all, or so it seems. They are also efficient tools to help develop new legal concepts.

\subsection{Metaphors spread the concept by spreading the word}

One undeniable asset that metaphors have is that, whether "dead" or "living", they are powerful devices that help spread legal notions, from the most basic to the most complex. For example, how come we know that the law is powerful? Not only because we see its effect in everyday life when it has not been adhered to, but also because we speak of it in terms that conjure up power. One of the most striking metaphors in this respect is the one that says that the law is a person. Not any person, however, although all the attributes of a normal human being may be used such as the brain, the conscience ("the conscience of Equity", to mention but one example), the spirit or the body. For instance, the law has arms. And if this arm is long ("long arm statute", "the long arm of the law") then it reaches beyond a country's boundaries. The law has eyes. But unlike any regular human being, its (her?) eyes can see everything as if it/she were a kind of omniscient power - reminiscence of the divine origin of Justice? Divine power aside, all these body metaphors indicate that the law can act. I have noticed that among the nouns that refer to body parts, «hand» is used in a remarkable number of phrases that, for the most part, appear in legal contexts: "document under hand", "hand and seal", "first hand evidence", "second hand evidence" - interestingly enough, the equivalent French phrase refers not to the sense of touch but to that of hearing (ouie dire) - "delivery by hand", "hand and official seal", "cash in hand"... The hand is precisely what gives human beings power over their environment. If we understand so well that the law has powers it is probably because we can relate to how it uses them, in the same way the ancient Greeks and Romans could relate to their gods in a typical case of anthropomorphism. The law ends up being thought of as a kind of supernatural human being - female, on the face of it, as confirmed by the phrase "our Lady the Common Law" to which I will return.

Some metaphors have allegedly helped spread legal notions efficiently - and probably more efficiently than a literal description would have. I do not intend to give a full appraisal of the metaphors which have successfully played this role. What I would like to show, however, is how efficient they can be in this respect.

That of the "golden thread" is a case in point. It was coined by Viscount Sankey, a Judge in the House of Lords, in his ruling in the Woolmington v. DPP case in $1935 .{ }^{9}$ His speech, known as "Viscount Sankey's Golden Thread Speech", read as follows:

Throughout the web of the English Criminal Law one golden thread is always to be seen that it is the duty of the prosecution to prove the prisoner's guilt [...]. No matter what the charge or where the trial, the principle that the prosecution must 
prove the guilt of the prisoner is part of the common law of England and no attempt to whittle it down can be entertained. [Viscount Sankey's Golden Thread Speech 1935: n. pag.] familiar that it is likely to take root not only in legal language but in non-specific language as well. This is the case, for instance, of the religious metaphor of the "fruit of the poisonous tree" which has given its name to a doctrine in the United States. It refers to illegally procured evidence which, as a consequence, is inadmissible in a court of law. 
Clearly, the evidence is seen as a poisonous apple that will kill the case of whoever has used/eaten it. Thanks to its metaphorical wording exempt of any legal term that could make it unpalatable to the average person - this is precisely one of the points of using metaphors in law - it becomes easy, then, to mention it in popular media such as movies (as is the case in Fracture [2007] for example) all the more so as it concerns a fairly banal situation that any American citizen can relate to. The American society is not only one of the most religious in the world ("the fruit of the poisonous tree" will ring a biblical bell with most Americans), it is also one that is allegedly the most acquainted with its legal system. Legal (and non legal) fiction may play a non-negligible role in this. We can assume that a virtuous circle is at work here: a legal concept can readily be referred to in fiction because it is worded metaphorically, and because it is mentioned people are likely to remember it, or at least accept it in a fiction that is not purposely legal ${ }^{12}$ - they are certainly more likely to welcome it than, say, "extrajudicial evidence", "extraneous evidence" or "rebuttal evidence" which sound a lot more technical.

\subsection{Metaphors and the Law: A Perfect Match?}

41 The magic of metaphors is that D1 and D2 merge in an apparently perfect match that brings them together by virtue of their common points. However, a metaphor can shed light only on a limited part of a concept, leaving the rest in the dark. In this way, the «agrarian metaphor in intellectual property discourse highlights only the individual nature of creation and the interest that a labourer has in the product of his or her labour», conveniently hiding "the effect of excessive copyright protection on the "marketplace of ideas"' Loughlan notes [2006: $224 \& 225]$.

Yet, is it useful or necessary to clarify everything? A metaphor fully plays its role when it makes it easy to grasp the gist of a concept. The merging of D1 and D2 is necessarily partial. It is also an illusion. It does not tell the truth, but $a$ truth. When we say, as Lakoff \& Johnson [2003: 7-8] underlined, "ARGUMENT IS WAR" or "TIME IS MONEY", the verb "be" emphasises the similarities between subject and predicate. Nonetheless, any similarity is "the place where identical and different aspects meet" as Ricœur [1975: 250] explains. ${ }^{13}$ As early as the Preface to his book [1975: 11], he notes that "metaphoric 'be' means both 'is not' and 'is like'." ${ }^{14}$ This is what we tend to forget, in particular when the metaphor is "dead" and as such easily overlooked. D1 is a filter - and perhaps even a philtre ${ }^{15}$ - which at best affects what we perceive of D2 and at worst utterly distorts our perception of it.

\section{Metaphors as manipulative and misleading devices}

A metaphor cannot but convey a point of view imposed by the source domain. This is not specific to the interpretation of metaphors in law. It is typical of the interpretation of any metaphor in any kind of context.

\subsection{Decoding is necessary}

For a metaphor to work properly, the recipient has to be able to identify "where the metaphor takes place" as summarised by Morier $[1981: 675]^{16}$, that is to say where D1 and D2 share a common ground. This is why: 
The formula $\mathrm{A} \cap \mathrm{B}=\varnothing$ equates with an absence of metaphor or a senseless

comparison. [Morier 1981: 677]

domain chosen as the reference for the comparison is therefore essential as "it determines the elements put forward: it works as a filter" Morier [1981: 677] concludes. Once this filter has been identified, the recipient needs to pick up which, among its many characteristics, must be taken into account. For instance, the image of a tree can be interpreted differently within the same culture. In the Judaeo-Christian world, it might conjure up the "poisonous tree" even to people who are not particularly religious probably even before they will think of the natural characteristics of a tree. The metaphors cited earlier work smoothly thanks to the adjectives that narrow the scope of the noun ("poisonous" and "living"), both of which are "naturally" or "culturally" readily associated with the noun "tree". As a consequence, decoding them requires a minimum amount of effort. In other cases though, it is more difficult, not to say downright impossible, to decipher the metaphor if the recipient does not possess the prerequisite knowledge to do so, be it legal, historical or linguistic. In any case, once the relevant elements have been duly selected, D1 plays its role as an access facilitator to D2 by laying down an interpretative framework. This framework automatically narrows the way the targeted concept is understood. It follows that a metaphor can be used as a powerful tool to impose how a notion is interpreted.

\subsection{Manipulative metaphors}

The aim of the metaphor may not be simply pedagogic: it can be misleading and manipulate the recipient. Why? Because language mirrors the way we see the world and conversely, the way we look at things depends on how we speak of them. In other words, language can narrow or at least circumscribe our understanding of reality - a feature that logically also characterises metaphors, which shape our thoughts as scholarship has shown in the past twenty years. For instance, if we speak of something in terms of war, we consider it as such (see Lakoff \& Johnson 2003). "These metaphors, while originally mythical or aspirational, become real and influence the way litigators think and behave. In addition to reflecting reality, they shape it", Thornburg [1995: 226] points out. This is why this author argues [1995: 228 \& 280] that if we want to change the way we conceive of a trial, we have to change the metaphors attached to it:

[...] we [should] adopt and nurture new metaphors that will emphasize those parts of the adversary system that are obscured by the currently dominant metaphors of war, sports and sex. [Thornburg 1995: 228]

As a consequence, metaphors are able to steer our perception of reality and notably of legal truth. Let us consider, for instance, the field of intellectual property. Loughlan [2006 $\& 2008$ ] has noticed that three metaphor clusters are to be found in this area of the law. One is the agrarian/bucolic metaphors which present creations as the "fruit" of the inventor's work that he/she is entitled to reap: "authors and inventors [are compared] to farmers who 'reap' and 'sow' and deserve the 'fruits' of their labours" she writes [2006: $211 \& 213]$. This metaphor is reinforced by that of the "sweat of the brow", which confirms the idea that any work deserves to be duly rewarded. "The agrarian metaphor is" she says [2006: 221] "an important linguistic resource for the originality doctrine in copyright law." It follows that if this "fruit" is reaped by someone else, that person has illegitimately taken what did not belong to them: it is theft, plain and simple. The 
conclusion sounds logical and perfectly understandable - which is precisely the point of such a metaphor as anyone must feel concerned by this "fact". Hence the second metaphor cluster that is pervasive in intellectual property: that of "theft" or "robbery" an even worse comparison since robbery implies violence. This, in turn, leads to another family of metaphors, as it appears ethical that a thief's actions must be fought harshly so as to preserve someone's rightful "property" (the word itself points to a reification process applied to an otherwise abstract creation):

[...] the 'pirate-predator-parasite' lend legitimacy and even urgency to another set of metaphors, namely, the metaphors of battle, or the armed and righteous aggressive action to be taken against the 'pirates'. [Loughlan 2006: 219]

We are back to armed Lady Justice, her sword and shield in hand. But how legitimate is that? Is it not mere lobbying on the part of an industry that does whatever it takes to protect its interests? At any rate, some scholars have questioned the string of negative connotations entailed by the original "bucolic" metaphors. Loughlan's statement is very clear in this respect:

[...] the use of the language of theft in the discourse of intellectual property ought at least to be constantly noted for what it is, an inaccurate and manipulative distortion of legal and moral reality. [Loughlan 2008: 2]

She exemplifies this with an everyday situation:

When the background authoritative voice in the MPAA film [...] intones that 'downloading a pirated film is stealing', no statement of law is being made. [Loughlan 2008: 5]

Maybe the metaphor is not - cynically enough - meant to manipulate, but there is no denying that its effects are to present an aspect of a reality as if it were the only possible one.

51 This communicative and manipulative power of metaphors can be even subtler. It is at work in another, commonplace statement that says that a "company/corporation is a person." The analogical process triggered by the verb "be" transfers some qualities typical of "a person" (D1) onto "a company/corporation" (D2). For most people, contrary to an animal a human being can laugh and can reason. The brain will immediately filter out the former quality as it obviously cannot be applied to a company and will focus on the latter. Reason means the capacity to act and the responsibility for one's actions. Indeed, a corporation can act like a real person (sign a contract, for example, or be sued) but as it is not made of flesh and bones, it is not a "natural" person but a "legal" person. This semasiological approach (going from the words towards the concept) seems to work fine. However, there is more to the metaphor. According to Greenwood, it is not just a person, it is seen as a citizen. "The consequences are dramatic", he says [2005: 3] because these "citizens" end up being granted more rights than regular citizens he contends [2005: 4]. Furthermore, by defining a corporation as a single person, the metaphor conceals the "groupness" and "the internal difficulties of aggregate decision-making" and claims [2005: 15], instead, "that a firm is a single, unified, pre-Freudian, actor." In other words, the metaphor misleads the recipients by making them accept that a company is a kind of "super person" or "super citizen". Some people are even prone to compare them to... superheroes: "[...] the thought of corporations as superheroes - rather than greeddriven villains of commerce - has some appeal in the environmentally and socially challenged society we have created", journalist Tyler Hamilton wrote on the website of Corporate Knights, under the title "Can corporations be superheroes?" 


$$
\begin{aligned}
& \text { led to the conception of the Common Law as a woman, possibly to trigger respect towards } \\
& \text { it, but not only. }
\end{aligned}
$$

ther metaphors lead to misconceptions of legal concepts. One of these is that which has

\subsection{Misleading metaphors - the gender of the law}

Is the law female, as the metaphor "our Lady the Common Law" suggests? It was coined by Sir Pollock, an authoritative historian of English Law, in his Carpentier lectures entitled "the genius of the common law" delivered at Columbia University in 1911, in which he gave an historical account of the development of this system of law. Over time a lot of writers have adopted the feminine image to speak of the Common Law, probably because of the force of the metaphor and the authority of its author. ${ }^{17}$ One notices that the noun "genius" in the lecture title initiates the personification process. "Our Lady" finishes it off by determining the gender: the Law is a "she". But she is not any woman: not only is she a genius, she is a goddess. A parallelism with Themis/Iustitia can and must be made here. As Sir Pollock stated early in his speech:

She is [...] armed and expectant [...]. She belongs to the kindred of Homer's gods [...]. She can be jealous with Hera, merciless with Artemis, and astute with Athena [...]. [Sir Pollock 1912: 6]

For that matter, the definition of "our Lady's" justice brings to mind that of Themis:

Her justice is fair as the moon, clear as the sun and terrible as an army with banners. [Sir Pollock 1912: 59]

Indeed, along with this "goddess" metaphor, the author also widely uses warfare metaphors: "She has faced many foes and diverse manner of weapons", he says [1912: 7]. "We have to consider the enemies of law and legal order in modern times", he adds [1912: 28]. "She looks for trusty servants who will stand by her in the day of need. She demands fearless and independent judges drawn from a fearless and independent Bar [...]. If our lady's servants are not of that spirit, all the learning of all their books will not save them from disgrace or her realm from ruin. If they are, we shall never see the enemy whom she and they will be afraid to speak with in the gate", he asserts as if to drive the point home [1912: 34]. The table of contents leaves no doubt as to the warlike and godlike aspects of the English Common Law in Sir Pollock's eyes at the time: "Our Lady and Her Knights", "The Giants and The Gods", "Surrebutter Castle", "Enemies in the Gate", "Rescue and Ransom", "Alliance and Conquest", "Perils of the Market-Place" and "The Perpetual Quest". Some writers such as Legrand [1992b: 945] have pointed out that the feminine metaphor is mainly meant to show English lawyers' respect for the Law. This view is supported by the use of the word "servants" as well as the fact that Sir Pollock declared in his speech that "our Lady the Common Law" deserves to be done homage to and worshiped.

Linguistically however, when it comes to translating in particular, the debate is still open as no evidence proves this standpoint is correct - no more than the opposite standpoint for that matter. Historically, "common law" stems from masculine noun phrases in Norman French (comun dreit, commun dreit, commune droit) as well as feminine noun phrases (lex communis, commune lei, commen ley). Though it would seem that the feminine phrases were more often used than their masculine counterparts, this is no reason to decide that the feminine should be prevalent today Legrand argues. As a matter of fact, he claims that the masculine article should be used in French (where the feminine article 
prevails in translations), as is the case in other languages such as Italian and Spanish [1992b: 945] where the noun is not gender neutral as it is in English. The reason for this is that «law» refers to droit (masculine) here and not to loi (feminine). Therefore, the phrase should read le Common Law. Yet, the feminine metaphor dies hard, as exemplified by Richard Cosgrove's book title Our Lady the Common Law: An Anglo-American Legal Community, 1870-1930 (New York: New York University Press, 1987) or this striking quote from an English judge that closes Galonnier's article [2000: \$27]: "The common law has not suffered a menopause and is not past the age of child bearing." She is clearly a woman (forever?) untouched by the ravages of time.

Is the metaphor really misleading? Yes, in so far as it presents for a fact something that is not supported by any historical proof and closes a debate that is still very much alive. This is what metaphors do. They present as an objective fact something that is merely a truncated truth, the goal being to reach a specific purpose. We can consider the goal as met when the metaphors have been properly decoded. However, this is far from always the case. A number of them are hard to decipher and as such are likely to totally blur the message... or do they?

\section{Metaphors as a source of obscurity?}

Some writers wish to eradicate metaphors in legal speech on the grounds that they make the understanding of legal concepts more complicated, which defeats their alleged purpose. Many among these writers support their point with examples of piled up, unrelated metaphors which draw from different domains to speak of D2, become intertwined and result in incoherent speech that obscures the message. However, I will set aside these "tortured" metaphors as Mellinkoff [1963: 26] calls them, because they are, in fact, a misuse of this figure of speech. This being said, can it be claimed, as part of Gardes Tamine's article title [2007] states, that "lexicalised metaphors [...] in specialised languages hinder comprehension"? ${ }^{18}$ In other words, these metaphors would blur the message altogether. The reason for this is they can be difficult to decipher [Gardes Tamine 2007: 18] because most metaphors in English for specific purposes are lexicalised. It turns out that a large number of them are impossible to figure out if one does not have a minimum amount of knowledge in the legal field concerned. Some can be guessed, such as "cloud on title" (or "clouded title"). ${ }^{19}$ But others cannot. Among those are metaphors resorting to very common semantic fields such as colours ("blue-sky law", "blue laws"20 or "blue ribbon jury"), cleanness or dirt ("dirt for dirt's sake", "clean and neat conditions"), body parts ("corruption of blood", "the Chancellor's foot"), cosmology ("cosmic law"), death ("dead copy", "dead pledge", "civil death"), animals and colours ("yellow dog contract"), family relationships ("son of Sam law") to name but a few (most of these metaphors are borrowed from Mellinkoff [1963]).

Yet, I would like to ask the opposite question: would a concept be easier to understand if it were defined literally? Something essential should be kept in mind: a technical concept evoked metaphorically does not lose its technicality. A metaphor does not erase conceptual complexities. It merely offers a signifier that is less dry and that opens the door, however slightly, to part of the concept. Sometimes though, the door opens to darkness for want of knowledge on the part of the recipient. However, literal language would surely fare no better. Firstly, because it would take a longer explanatory sentence. For instance, let us consider the "clean hands" metaphor: "The language chosen 
expresses in the vivid, concrete terms of daily human life, an abstract principle of legal reasoning about denial of relief to a plaintiff whose own conduct has been improper", Loughlan [2006: 213-214] explains. Or "The Silver Platter Doctrine" which, as Mellinkoff [1963: 441] defines it, is "The law of the sanctimonious federal - his hands unsoiled by the illegal search, yet claiming the damning proceeds - could be remembered more easily as the silver platter doctrine" (Mellinkoff specifies that the metaphor was drafted by Justice Frankfurter in 1949 in Lusting v. United States, 338 U.S. 74, 78-79). The metaphor remains more efficient than a literal explanation (for instance: "the exclusionary rule - valid until 1960 - that allows federal courts to accept evidence seized illegally by state"). It highlights the essence, or what matters most, i.e. the evidence is served to the courts on a silver platter. Some elements are missing, it is not perfect but partial as most metaphors are, but at least the core of the doctrine is easily remembered and presented in a few words based upon a well-known phrase belonging to everyday language. This illustrates perfectly what Berger argues:

[...] even the most conceptual and theoretical ideas find explication through analogy to common phenomena. [Berger 2002: 34]

Secondly, literal language would not express complex concepts in a less complex manner than metaphors do. It would rather be the opposite. As Morra, Rossi \& Bazzanella put it:

A metaphor is not a way of saying something that could be said literally, it is rather a productive tool useful for categorising experiences or ideas that cannot be described through pure referential expressions and literal language. [Morra, Rossi \& Bazzanella 2006: 144-145]

The word "obscurity" in the title deserves some discussion. The question is: who are such metaphors obscure to? No doubt to anyone who does not have the required legal and/or cultural knowledge. As a matter of fact, "obscurity is only rarely a barrier to understanding", Charnock [2006: 65] argues. The obscurity created by some metaphors is indeed relative. Metaphors use plain words but they are not plain language. They belong to symbolic language. A language that the average person is not always likely to understand or is not even meant to understand. For instance, the "clean hands" metaphor or the "silver platter doctrine" metaphor refer to very specific concepts that only lawyers are expected to master. As such, not only is such wording not detrimental to comprehension but it also offers the additional advantage of being not only "rememberable but memorable" [Mellinkoff, 1963: 440].

\section{Conclusion: "Metaphor, in short, is here in law and it is here to stay"21}

62 Most metaphors in English for Law are lexicalised. As such, they belong to the legal lexicon. Their aim is to present legal concepts in a memorable, vibrant and concise manner that uses plain vocabulary and establishes a comparison with a domain that is culturally easy to relate to. Yet, let us not be fooled by a plain English signifier. The use of such vocabulary does not mean that technicality is eradicated from the concept. Those which are less technical are efficiently conveyed through a metaphor. But those which are complex are conveyed just as efficiently.

63 The point is not to make legal concepts accessible to everybody (though some do). It is to make them strike the mind. Even if I do not know precisely what the "Silver Platter Doctrine" is, I can figure out what the general concept is about, however complex it is. 
Besides, the metaphor is likely to sink in. In the same way, an American lawyer will presumably remember the meaning attached to it precisely because it is drafted metaphorically. This is why metaphors are useful in law. They successfully play a role that literal language would not perform any better and probably not as well for it would lack what makes metaphors so powerful. As such, the law gains more than it loses in using them, as long as they are used properly. What is proper use? One that does not collide with another, unrelated metaphor whether it is to describe the same concept or a different concept. Let us not forget that the analogical process is indirect and requires some decoding effort. A text crammed with metaphors would probably be as unpalatable as one crammed with technical terms. As Antoine de Rivarol beautifully put it: "he who would speak of everything in technical terms should be kept at arm's length."22 The same could be said of whoever would constantly speak in metaphorical terms. But misuse aside, metaphors are probably one of the most efficient stylistic tools to communicate legal concepts. They do have flaws, which should not be overlooked or underestimated, but they remain a powerful communicative linguistic device whose advantages far outweigh their disadvantages.

\section{BIBLIOGRAPHY}

\section{Books \& Articles}

BERGER Benjamin L., "Trial by Metaphor: Rhetoric, Innovation, and the Juridical Text”, Court

Review, The Journal of the American Judges Association, Vol. 39, n 3, Paper 133, 2002: 1-9.

http://digitalcommons.unl.edu/ajacourtreview/133. Web. 7 March 2013.

BINNIE Ian, "Interpreting the constitution: the living tree vs original meaning", Options politiques/

Policy Options, « Freetrade/Le libre échange », Montréal: Institut de Recherche en Politiques

Publiques, 2007, 104-110.

www.irpp.org/po/archive/oct07/binnie.pdf. Web. 26 Feb. 2013.

CHARNOCK Ross, "Clear Ambiguity", in WAGNER Anne \& CACCIA GUIDI-FAHI Sophie (Eds), Legal

Language and the Search for Clarity - Practice and Tools, Bern: Peter Lang, 2006 : 65-103.

CORNU Gérard, Vocabulaire juridique, Paris : PUF, 1992 [1987]

Cosgrove Richard A., Our Lady The Common Law, New York \& London: New York University Press, 1987.

CUNILERRA DOMÈNECH Montserrat, «Les métaphores dans le discours politique : tendances de traduction à l'espagnol », Synergies Espagne $n^{\circ} 3$ " Contrastes linguistiques et communication », 2010 : 107-117.

http://ressources-cla.univ-fcomte.fr/gerflint/Espagne3/montserrat.pdf. Web. 6 Aug. 2012.

FAIRGRIEVE Duncan \& MUIR WATT Horatia, Common Law et tradition civiliste, Paris : PUF, 2006. 
FUMAROLI Marc, Le livre des métaphores, Paris : Robert Laffont, 2012.

GALONNIER Bernard, «La métaphore dans les jugements anglais : nature et fonction», Asp 27-30, 2000, 325-335.

http://asp.revues.org/2260. Web. 16 April 2013.

GARDES TAMINE Joëlle, « Les métaphores dans la langue et dans les langues de spécialité : un obstacle à la compréhension », 2007.

http://ressources-cla.univ-fcomte.fr/gerflint/Italie3/joelle.pdf. Web. 5 Aug. 2012.

GIAUFRET Anna \& ROSSI Micaela, « Métaphores terminologiques, circulation des savoirs et contact entre langues », Signes, Discours et Sociétés [online] 10, «La métaphore dans les discours spécialisés», 2 Feb. 2013.

http://www.revue-signes.info/document.php?id=2928 ISSN 1308-8378. Web. 2 March 2013.

GINGRAS Anne-Marie, « Les métaphores dans le langage politique », Politique et société n³0, 1996, 159-171.

www.erudit.org/revue/ps/1996/v/n30/040037ar.pdf. Web. 6 Aug. 2012.

GOMBARO Antonio, SACCo Rodolfo \& VOGEL Louis, Le droit de l'occident et d'ailleurs, Paris : LGDJ, 2011.

GREENWOOD Daniel J.H., "Introduction to the Metaphors in Corporate Law", Seattle Journal for Social Justice, Utah Legal Series Paper 05-13, 2005: 1-17.

http://ssrn.com/abstract=797564. Web. 7 July 2012.

HOUBERT Frédéric, «Caught in the Web of the Law : le traducteur juridique face à la métaphore ", $2008: 1-15$

http://www.initerm.net/post/2011/05/18/Les-metaphores-juridiques. Web. 1 June 2012.

LAKOFF George \& JOHnSON Mark, Metaphors We Live By, London: The University of Chicago Press, 2003 [1980].

LEGRAND Pierre, Common Law d'un siècle à l'autre, Québec : Yvon Blais, 1992a.

LEGRAND Pierre, « Pour le common law », in Revue internationale de droit comparé. Vol. $44 \mathrm{~N}^{\circ} 4$, Octobre-décembre 1992, 1992b : 941-947.

http://www.persee.fr/web/revues/home/prescript/article/

ridc_0035-3337_1992_num_44_4_4577. Web. 1 March 2013.

LÉVY-ULLMANN Henri, Le système juridique de l'Angleterre, coll. « Les introuvables - droit comparé », Paris : Éditions Panthéon-Assas, 1999.

LOUGHLAN Patricia, « Pirates, Parasites, Reapers, Sowers, Fruits, Foxes... The Metaphors Of Intellectual Property ", Legal Studies Research Paper n 06/01, Sydney Law Review, Vol. 28, n² 2, 2006

:211-226

http://papers.ssrn.com/sol3/Papers.cfm?abstract_id=919560. Web. 24 Feb. 2013.

LOUGHLAN Patricia, “'You wouldn't steal a car', Intellectual Property and the Language of Theft”, Sydney Law School Research Paper $n^{\circ}$ 08/35, European Intellectual Property Review, Vol. 29, $\mathrm{n}^{\circ}$ 10, 2008: 401-405, http://ssrn.com/abstract=1120585. Web. 4 Nov. 2012.

MELLINKOFF David, The Language of the Law, Boston, Toronto: Little, Brown and Company, 1963. MORIER Henri, Dictionnaire de poétique et de rhétorique, Paris : Presses Universitaires de France, 1981 [1961]. 
MORRA Lucia, ROSSI Piercarlo \& BAZZANELLA Carla, “Metaphor in language: Clarity or Obscurity?", in WAGNER Anne \& CACCIA GUIDI-FAHI Sophie (Eds), Legal Language and the Search for Clarity - Practice and Tools, Bern: Peter Lang, 2006: 141-174.

PICARD Étienne, Dictionnaire de la culture juridique, Paris : PUF, 2003.

PICOTTE Jacques, « Apport de la jurilinguistique à la lexicographie jurilinguistique : l'exemple du Juridictionnaire », in SNOW Gerard \& VANDERLINDEN Jacques (Eds), Français juridique et science du droit , Brussels : Bruylant, 1995: 295-310.

POLLOCK Frederic, The Genius of the Common Law, Columbia: Columbia University Press, 1911. http://www.912freedomlibrary.org/custom-1/Genius of comm. Web. 7 June 2013.

RICOEUR Paul, La métaphore vive, Paris : Le Seuil, 1975.

ROUETTE Georges, « Le genre de 'Common Law' », in SNOW Gerard \& VANDERLINDEN Jacques (Eds), Français juridique et science du droit, Brussels : Bruylant, 1995: 311-325.

THORNBURG Elizabeth, "Metaphors Matter: How Images of Battle, Sports and Sex Shape the Adversary System”, Wisconsin Women's Law Journal, Vol. 10, 1995: 225-281.

http://papers.ssrn.com/sol3/papers.cfm?abstract_id=1006305. Web. 24 Feb. 2013.

TRIM Richard, Metaphor Networks - the comparative evolution of comparative language, New York : Palgrave Macmillan, 2007

STIRN Bernard, FAIRGRIEVE Duncan \& GUYOMAR Mattias, Droits et libertés en France et au Royaume Uni, Paris : Odile Jacob, 2006.

\section{Dictionaries}

CAMPBell BlaCK, Henry, Black’s Law Dictionary, Minnesota: West Publishing Company, 1991 [1983].

The Free Dictionary, Legal Dictionary, http://legal-dictionary.thefreedictionary.com/, Web. 3 Sept. 2012.

\section{NOTES}

1. "If $A=B$ represented a perfect identity, then it would not be a comparison [...] nothing would be stated other than A=A: 'an ant is [like] an ant" [Morier 1981: 674] / " Si A=B représentait une identité absolue, ce ne serait plus une comparaison [...] on n'affirmerait rien d'autre que $A=A$ : 'une fourmi est [comme] une fourmi' ».

2. Mellinkoff [1936: 515] develops this point further.

3. For instance, Ricœur [1975: 216] states that: "there are no [...] metaphors in dictionaries"/« il n'y a pas [...] de métaphores dans les dictionnaires ».

4. This point is developed by Gombaro, Sacco \& Vogel [2011: 45-46].

5. «Sans discontinuité, le droit positif remonte dans l'histoire jusqu'aux temps immémoriaux [...] en Angleterre. On peut même aller jusqu'à dire que plus une règle est ancienne, plus elle a de poids. L'autorité s'attache à l'ancienneté ".

6. See Houbert [2008: 5] for more detail.

7. Associated Provincial Picture Houses Ltd v. Wednesbury Corporation [1948] 1 KB 223.

8. «Dans toute son histoire, le Common Law tout à la fois change et ne change pas, exactement comme un fleuve qui coule, qui reste le même en n'étant jamais le même ». It is interesting to 
notice that Picard uses the masculine genre to speak of the Common Law when other writers opt for the feminine. I will return to this.

9. Woolmington was charged with killing his wife who had left him a month earlier. He claimed the gun had fired accidentally. The issue at stake was the statement of law in 'Foster's Crown Law' (1762) according to which "where a death occurred it is presumed to be murder unless proven otherwise."

10. See Houbert [2008: 10] for more detail.

11. A case "where the courts in Canada embarrassed themselves by holding, in accordance with the 'original meaning' of Section 32 of the Constitution Act, 1867, that women were not qualified for appointment to the Senate because they were not "qualified persons", Judge Binnie of the Supreme Court of Canada [2007: 105] wrote.

12. A study of metaphors in fiction in general, and in legal fiction more specifically, could prove helpful in checking this hypothesis.

13. "Toute ressemblance est le] lieu de rencontre entre le même et le différent ».

14. "Le 'est' métaphorique signifie à la fois 'n'est pas' et 'est comme' ».

15. A charm potion that beguiles.

16. "[le] lieu de la métaphore ». Morier notes that this "place" is sometimes called "the heart" or "the knot" or "the nexus".

17. This argument is developed by Rouhette [1995: 311].

18. «[...] les métaphores lexicalisées [...] dans les langues de spécialité » sont « un obstacle à la compréhension ».

19. It is "an outstanding claim or encumbrance which, if valid, would affect or impair the title of the owner of a particular estate" (Black's Law Dictionary, 1991: 175). It is interesting to note that the action to claim the estate in question is also named metaphorically. It is a "quiet title action" defined as follows: "A quiet title suit is also called a suit to remove a cloud [...]. [It is] a lawsuit to establish a party's title to real property against anyone and everyone, and thus «quiet» any challenges or claims to the title" (The Free Dictionary online).

20. "A statute [is] called a 'Blue Sky Law' because it pertains to speculative schemes which have no more basis than so many feet of blue sky", Black's Law Dictionary explains [1991: 118]. Blue Laws are "statutes regulating entertainment activities, work, and commerce on Sundays. Such laws have their origin in colonial New England", according to Black's Law Dictionary [1991: 118]. Hypotheses have been put forward to account for the adjective «blue». One is the assumption that the first of such laws were printed on blue paper or that they were compiled in books with a blue cover. The metaphor would therefore be based upon a synecdoche.

21. This quote is borrowed from Loughlan [2006: 216].

22. "[...] celui qui parlerait de tout en termes techniques serait un homme à fuir ", «Prospectus du nouveau dictionnaire », Discours préliminaire du nouveau dictionnaire de la langue française, first part, Hamburg, P.F. Fauche, 1797. Quoted by Fumaroli [op. cit: 6].

\section{ABSTRACTS}

A large number of legal concepts is expressed through metaphors, exemplifing the Conceptual Metaphor Theory created by Lakoff \& Johnson. Indeed, the law often resorts to metaphors in order to allow us to understand an abstract and/or unknown concept in terms of another that is 
concrete and/or familiar (the metaphor of the "living tree" to describe some aspects of the Canadian constitution is a case in point). The law itself is often compared to an object ("to break the law", "a law breaker") or to a person ("Our Lady the Common Law", "the arm of the law", "the eye of the law"). What is more, some metaphors have allegedly contributed to developing new legal concepts (for instance the metaphor of "the golden thread" was used to evoke the then new notion of the presumption of innocence in Canada).

However, though it cannot be denied that metaphors are useful to shed light on legal concepts, the interpretation of the latter is necessarily biased because the compared concept is always circumscribed to the comparing concept which, besides, tends to present the interpretation as the only possible one. This way, some metaphors can be used as manipulative tools.

Finally, the cognitive function of metaphors may be limited: on the one hand, some metaphors may remain obscure even to the native speaker ("blue sky law", "thin skull doctrine"), on the other hand, others may be misleading either because they are ambiguous or because they suggest (impose?) one vision of the world that excludes all the others.

Un grand nombre de concepts juridiques est exprimé au moyen de métaphores. Leur emploi illustre la théorie de la métaphore conceptuelle élaborée par Lakoff \& Johnson: le droit a fréquemment recours à la métaphore afin de faire comprendre un concept inconnu et/ou abstrait au moyen d'un autre connu et/ou concret (par exemple la métaphore de "l'arbre vivant " pour décrire certains aspects de la constitution canadienne). Le droit lui-même est comparé à un objet (" to break the law », « law breaker ») ou bien à une personne ("Our Lady the Common Law », "the arm of the law ", «the eye of the law »). En outre, certaines métaphores auraient contribué au développement de nouveaux concepts (telle celle du «fil d'or» pour évoquer la présomption d'innocence au Canada).

Cependant, si la métaphore semble indispensable au droit, elle est également un filtre qui oriente l'interprétation des concepts juridiques: le comparé est circonscrit au comparant qui, de surcroît, présente l'interprétation comme la seule possible. Certaines métaphores peuvent alors être utilisées à fins de manipulation.

Enfin, la fonction cognitive des métaphores se heurte à des limites : d'une part, certaines peuvent demeurer obscures, y compris aux locuteurs natifs («blue sky law», "thin skull doctrine»), d'autre part, elles peuvent induire en erreur soit parce qu'elles sont ambiguës, soit parce qu'elles proposent (imposent ?) une vision du monde à l'exclusion de toute autre.

\section{INDEX}

Mots-clés: métaphores mortes, concepts juridiques, visée pédagogique, interprétation des concepts juridiques

Keywords: dead metaphors, legal concepts, pedagogic power, interpretation of legal concepts

\section{AUTHOR}

\section{ISABELLE RICHARD}

Aix-Marseille Université (AMU), France - LERMA, EA 853

isabelle.richard@univ-amu.fr 